denied the accusation that science is responsible for the horrors of war; dismissed the proposal that scientific workers should refuse to do war work as impracticable; urged them to join with the general public in order to take the necessary political action to stop the use of science for purposes of destruction, and suggested finally that the most suitable form of action would be the setting up of an international police force under the auspices of the League of Nations. Air Commodore Charlton showed how one of the principal technical achievements of our age, the aeroplane, has brought war to our doorstep, and has made the world population centres, such as Londan, the principal military objective in a future war. $\mathrm{He}$ presented quantitative evidence of the inadequacy of all known methods of defence, and urged scientific workers to devise something that would render the use of bombers impossible. In the subsequent discussion, attention was directed to the alternative policies advocated for avoiding war. The general consensus of opinion seemed to be in favour of some system of genuine collective security, and rejected both the isolationist and the pacifist solutions. J. D. Bernal reported the principal recommendations of the Science Section of the International Peace Conference held in Brussels last September. These included the proposal that scientific workers should apply scientific method to the study of war in all its aspects, to investigate the causes of war from the point of view of social and biological science, and to expose pseudo-scientific theories justifying war and racial superiority. It was finally proposed that a national commission representing all branches of science be set up to co-ordinate this work. These recommendations met with the warm support of the meeting.

\section{Social Mission of Science}

TrE "Social Mission of Science", which formed the subject of a leading article in NATURE of October 24, has no more important objective, according to Prof. John Dewey, the veteran philosopher of Columbia University, than to elucidate the relation between authority and freedom. In his address at the Harvard Tercentenary Conference of Arts and Sciences on September 4 on "Authority and Resistance to Social Change" (School and Society, October 10), he exposed two fallacies underlying much of the philosophy that has gone by the name of liberalism, namely, that authority and freedom have separate and independent spheres of activity and no form of authority is justifiable that is not the product of, and sanctioned by, the conscious wants, efforts and satisfactions of individuals in their private capacity. While decrying the principle of authority, this philosophy, in fact, erected the wants and endeavours of private individuals seeking personal gain to the place of supreme authority in social life. Its failure to produce the conditions of a generally shared individual freedom is largely responsible for the recrudescence of the principle of authority in its most extreme and primitive form-the rise of dictatorships.
No collective planned economy, Prof. Dewey said, will succeed without some hitherto untried means for bringing into life an organic co-ordination of authority and freedom. It is here that science may help. It is suggested that the working of co-operative intelligence as displayed in science may serve as a working model of the union of freedom and authority. Here is seen individual freedom that is both supported by collective organized authority and, in turn, changes and is encouraged to change and develop by its own operation the authority upon which it depends. The extension to the wider field of human relations of the method of control by organized intelligence operating through the release of individual powers and capabilities presents enormous difficulties, but it is, Dewey holds, the only means whereby humanity can be rescued from "that futile and destructive oscillation between authoritative power and unregulated individual freedom to which we may justly attribute most of the sorrows and defeats of the past".

\section{The Permanent International Studies Conference}

THE report on the work of the Intellectual Co-operation Organisation, subrnitted by the Sixth Committee to the Assembly of the League of Nations, refers to the expansion of the Permanent International Studies Conference, which is now engaged in an objective and scientific study of foreign policy. This is an autonomous body which is able to pursue its work in the complete independence proper to scientific research. The most recent subjects dealt with by the Conference are State intervention in economic life, the possibility and conditions of an organization of collective security, and peaceful methods of change as applied to particular problems. For 1936 and 1937, the subjects chosen include the procedures for the peaceful settlement of disputes which have been applied in particular cases, over-population, colonies, migration and distribution of raw materials. In the field of education, an important result of the year's work of the Committee has been the publication by the Paris Institute of a first volume dealing with the organization of higher education and research in several European and American countries, while the Committee's efforts in the teaching of history are bearing fruit in the revision of text-books.

SPECIAL interest is attached to the attention which the International Committee is now giving to the question of unemployment among intellectual workers. While this question cannot be separated from the problem of unemployment as a whole, and the remedies to be recommended are chiefly national in character, international action may be of great value, particularly in the nature of co-operation between university information bureaux. Closer relations are being established between the Intellectual Co-operation Organisation and the International Council of Scientific Unions, and a permanent scientific committee is being set up as a result of the meeting of an expert committee to develop the Organisation's work in this field, and conversations on scientific 